лять ориентированную профессиональную самооценку личности, которая может изменяться, находить оптимальный индивидуальный стиль работы, изучать проблему общения и формирования самооценки личности, педагогу обращаться к собственному опыту, определяя наиболее эффективные методы и технологии межличностного взаимодействия со студентами $[11$, c. 66].

Рассмотренные проблемы побуждают авторов приступить к дальнейшему исследованию поисков взаимосвязи художественного творчества и содержания гуманитарного образования, а также к определению наиболее эффективных методов и приёмов внедрения такого единения в учебный процесс.

Список литературы

1. Рубинитейн С. Л. Проблемы общей психологии. Москва, 1973. 489 с.

2. Сенько Ю. В., Тамарин В. Э. Обучение и жизненный познавательный опыт. Москва, $1989.77 \mathrm{c}$.

3. Федотова Л. Е. Преемственность уровней образования в условиях ФГОС // Здоровье основа человеческого потенциала: проблемы и пути их решения. 2020. № 3. Том 15. С. 10991103.

4. Архипова С. В. Преемственность в образовании: социологический анализ: автореф. дис. ...канд. социол. наук. Екатеринбург, 2009. 19 с.

5. Зайниев Р. М. Преемственность профессионально-ориентированного содержания математического образования в системе «школа- колледж-вуз»: автореф. дис. ... д-ра пед. наук. Ярославль, 2012. 43 с.

6. Рягин С.Н. Преемственность среднего общего и высшего профессионального образования в условиях их системных изменений: автореф. дис. ... д-ра пед. наук. Москва, 2010. 43 с.

7. Кожевникова О.В. Преемственность в образовании: представления участников образовательной системы о выпускнике школы // Педагогическое образование в России. 2013. № 1. C. 86-93.

8. Лукьянова 3. Н. Психологические условия формирования позитивного отношения у студентов образовательных учреждений к предметам общегуманитарного цикла // Мир науки, культуры, образования. 2018. № 4. C. $68-70$.

9. Комаристая Л. А. Формирование исторического мышления и проблемы повышения качества образования в условиях совершенствования ФГОС // Качество образования в сфере культуры и искусств в условиях реализации ФГОС ВО. Барнаул, 2015. C. $135-138$.

10. Борзенко И. Л. Конкурс "Этнические корни" как средство развития интереса к национальной культуре // Проектно-технологические и организационно-методические аспекты деятельности этнокультурных коллективов. Барнаул, 2014. С. 124-130.

11. Лукьянова 3. Н. Влияние самооценки личности на характер общения школьников и студентов. Барнаул, 2020. 164 с.

\title{
КУЛЬТУРНО-ХОРЕОГРАФИЧЕСКОЕ НАСЛЕДИЕ АЛТАЙСКОГО КРАЯ: СОХРАНЕНИЕ И РАЗВИТИЕ ШКОЛЫ КЛАССИЧЕСКОГО ТАНЦА
}

Аннотация. В статье рассматривается роль классического танца в контексте культурного наследия Алтайского края, необходимость изучения классического наследия балета в современном образовании хореографов, определяется его важность в системе хореографического обучения участников любительских и профессиональных хореографических коллективов различной жанровой направленности в условиях регионального культурного пространства. Раскрывается деятельность ведущих педагогов-хореографов по обучению воспитанников сложным формам классического жанра танца. Выявляются возможности классического танца в формировании системы профессиональных компетенций будущих педагогов-хореографов. 
Ключевые слова: культурно-хореографическое наследие, классический танеи, ведущие педагоги классического танца на Алтае, деятельность любительских коллективов классического танца, профессиональные компетенции педагога-хореографа.

Классический танец как жанр хореографического искусства в контексте культурного наследия - одна из актуальных тем профессионального образования хореографов. Необходимость ее исследования обусловлена повышением качества обучения выпускников образовательных учреждений. В процессе изучения и постижения выразительных средств и форм движений классического танца приобретаются компетенции первостепенно необходимые в профессиональной деятельности будущих хореографов. В процессе усвоения классических образцов естественно повышается сценическая культура тела, эстетически осмысленной становится пластика исполнителя танца. Таким образом, необходимо обобщить, что в системе различных моделей обучения классическому танцу (любительские коллективы, школы искусств, дома творчества, высшие и средние учреждения образования в сфере культуры и искусства и др.) важным становится формирование классической школы сценического исполнения.

Ведение тренажа на основе классического танца позволяет целенаправленно высвобождать физические данные и танцевальные способности. Систематические тренировки по методике классического танца, как показывает опыт, результативно совершенствуют физический аппарат танцовщика: гибкость, пластичность, баллон, координацию, быстроту и легкость в исполнении движений, подвижность стопы, шаг, фактуру тела, то есть характеристики, которые относятся к понятию «выразительное тело». На сегодняшний день, как показывает опыт, владение средствами классического танца является неотъемлемым условием для успешной работы педагога-хореографа.

Изучение классического наследия в области балета тесно сопряжено со знаниями по «Истории мировой художественной культуры», «Теории и истории искусства», «Наследие и репертуар» и, практически со всеми хореографическими дисциплинами: «Историко-бытовым танцем», «Народно-сценическим танцем», «Современным танцем», «Бальным танцем» и пр. Связи обусловлены следующим основанием: формирование системного знания будущих выпускников-хореографов в контексте развития и вырабатывания представления о состоянии современного хореографического образования возможно на пути интеграции содержания пред- метных курсов образовательной программы по направлению подготовки «Народная художественная культура». При этом, необходимо понимать, что в современном хореографическом образовании велика роль региональных особенностей развития школы классического танца.

Предусмотренный данной программой практический курс по освоению классических образцов танца в необходимой мере позволяет овладеть базовыми формами классического танца, а также изучить работу с музыкальным материалом классических балетов. Практические занятия предполагают изучение и исполнение конкретных примеров - образцов из классического репертуара: па-де-труа из балета «Щелкунчик» в постановке В. Вайнонена; вариации Сюимбике из балета Ф. Яруллина «Шурале» в постановке Л. Якобсона; вариации Китри из балета Л. Минкуса «Дон-Кихот» в постановке А. Горского; вариации Сванильды из балета М. Делиба «Коппелия» в постановке Ф. Лопухова; танца маленьких лебедей из балета П. Чайковского «Лебединое озеро» в постановке Л. Иванова и др.

Постижение классических образцов в учебном процессе позволяет обучающимся поднять исполнительское мастерство на высший художественный уровень, а также творчески влиять на процесс становления профессиональных компетенций. Постепенно у обучающихся хореографов формируются системные знания, направленные на понимание сущности и специфики классического танца в контексте культурно-хореографического наследия. Обучающиеся хореографы начинают относиться к классическому наследию как к образцу, эталону хореографического мастерства, признанному всеми в образовательном хореографическом пространстве. Классические образцы имеют длительную сценическую жизнь, считаются шедеврами хореографического искусства, его «золотым фондом».

Сформированная профессиональная позиция к классике на этапе обучения в образовательном учреждении в дальнейшем поддерживается в опыте работы выпускниковхореографов. Но «прочесть энциклопедию русской школы классического танца равновелико стилю и эпическому величию Петипа» по меткому замечанию балетного критика В. Уральской могут не все [1, с. 15]. Исполни- 
тельское мастерство часто бывает безликим, а вариации лишены индивидуального подхода.

В контексте формирования школы классического танца в Алтайском крае следует вспомнить и отметить роль Народного театра балета дома культуры Барнаульского меланжевого комбината под руководством М. А. Зарайской, творческая деятельность которой связана с этим коллективом с 1948 по1962 гг. Кроме того, в этом коллективе, начиная с 1962 г., работали балетмейстеры: А. К. Саркисян, В. А. Преображенский, М. А. Миксер, Л. И. Крылов [2]. В дальнейшем деятельность этого коллектива в советский период, начиная с 50-х гг. ХX столетия, связана с постановкой многих классических образцов. Репертуар театра формировался на основе изучения классических балетов и отдельных номеров: «Половецкие пляски» из оперы А. П. Бородина «Князь Игорь»; «Вальпургиева ночь» на музыку Ш. Гуно; «Бахчисарайский фонтан» композитора Б. Асафьева; «Лауренсия» на музыку А. Крейна, «Корсар» на музыку А. Адана и др. Местные газеты и центральная печать неоднократно отмечали творческие успехи этого коллектива [3, с. 61].

С 1976 г. в театре начинает работать Л. С. Силантьева. Её первый балет «Карменсюита» на музыку Ж. Бизе - Р. Щедрина получил высокие отзывы на смотре художественной самодеятельности в г. Барнауле (1977 г.). Театр с этого времени начинает обновлять свой репертуар, появляются этапные спектакли «Коппелия» (музыка Л. Делиба), «Ромео и Джульетта» на музыку С. Прокофьева, «Героическая симфония» С. Рахманинова и др. Индивидуальный подход к воспитанникам, умение заинтересовать участников коллектива исполнением классических образцов. Тонкое чувство красоты, по свидетельствам очевидцев, характеризуют личность этого талантливого педагога [4, с. 51].

В истории становления школы классического танца в Алтайском крае важную роль в 70-80 гг. ХХ столетия сыграл балетмейстер Алтайского краевого театра музыкальной комедии Н. 3. Громов. Он в 1975 году на базе театра организовал балетную студию. Талантливые воспитанники обучались три года в этой студии и далее получили путевку в профессиональный мир танца: кто-то стал исполнителем в профессиональных коллективах края, а кто-то продолжил обучение в Алтайском государственном институте культуры и стал сам преподавать классический танец. Уроки в студии проводились по системе А. Мессерера, у которого получил знания сам Н. 3. Громов [5, с. 33].
В контексте тематики статьи необходимо сказать о педагогической деятельности Н. Н. Кровяковой, выпускнице Алтайского государственного института культуры, ученицы В. В. Пуйовой - первой заведующей кафедрой хореографии Алтайского государственного института культуры. В этом году у кафедры 45-летний юбилей. Ансамбль классического танца «Эос», которым руководит Н. Н. Кровякова, является действующей творческой площадкой кафедры.

Самые первые основы мастерства классического танца Н. Н. Кровякова постигала под руководством Людмилы Александровной Батаниной, которая и в настоящее время работает с воспитанниками «Эоса», нарабатывает с ними технику и развивает умение держаться на сцене, органично существовать в образах классического репертуара. Вместе с Н. Н. Кровяковой работала с ансамблем выпускница кафедры хореографии Алтайского государственного института культуры Р. М. Шишина, которая предложила дать ансамблю имя античной богини утренней зари «Эос». Все участники коллектива одобрили это романтическое нежное имя с восторгом.

Буквально на глазах у зрителей первоначальная студия превращалась в зрелый ансамбль классического танца. Первые постановки коллектива - «Вальс» на музыку Д. Шостаковича и «Ноктюрн» на музыку $\Phi$. Шопена, триптих «Возрождение» на лютневую музыку, «Жанна» на музыку Г. Генделя. В 1982 г. на сцене Дворца шинного завода «Эос» дал первый полноценный вечер балета. Классический репертуар ансамбля отражает неотъемлемую составляющую учебного процесса. Много известных классических балетов осуществлено в этом ансамбле: «Дон-Кихот» (1998 г.), «Баядерка» (1999 г.), «Шопениана» (2000 г.).

Из этого коллектива вышла целая плеяда педагогов классического танца, которые работают в школах искусств, колледже и институте культуры, руководят известными в крае коллективами классического танца: О.А. Левицкая, Р. А. Вейн, Н. Г. Рылеева, Л. В. Сибирякова, Н. В. Губанова. Многие выпускники Н. Н. Кровяковой работают артистами в профессиональных коллективах Алтайского края [6]. Для того, чтобы пройти этот путь становления профессионала, нужно обладать душой художника и выносливостью спортсмена, уметь преодолевать все трудности, безудержно любить балет, чтобы постоянно совершенствовать свое мастерство и творить чудеса на сцене. 
Исходя из вышесказанного, можно сделать вывод, что школа классического танца на Алтае продолжает развиваться, бережно сохраняет и преумножает традиции своих первопроходцев, целенаправленно воспитывает в своих учениках любовь к классическим образцам, искусству высокого танца, осознание роли классики в формировании личности хореографа профессионала.

Огромные возможности классического танца можно обнаружить и в формировании системы профессиональных компетенций будущих педагогов-хореографов. Прежде всего, классический танец направлен на формирование целого комплекса художественного (условного) языка танца, отличного от бытовой пластики, который эстетически базируется на совершенных навыках владения физическим аппаратом исполнителя. Но при исполнении классических «па» нельзя думать только о технике движений. В мышечной памяти исполнителя на уровне закрепленного двигательного навыка остается не только внешняя форма движения, но и его внутреннее эмоционально-психологическое содержание.

\section{Список литературы}

1. Уральская В. «Пахита» или путь к себе самим // Балет. 2009. № 1.С. 15-16.

2. Сибирякова Л. В. Балетмейстеры Народного театра балета Дома культуры Барна- ульского меланжевого комбината // Ученые записки (Алтайская государственная академия культуры и искусств). Танцевальное искусство и образование. 2018. № 4 (18). С. 52-57.

3. Смолянинова Н. И. Роль М. А. Зарайской в становлении и развитии народного театра балета // Ученые записки (Алтайская государственная академия культуры и искусств). Танцевальное искусство и образование. 2018. № 4 (18). C. 58-63.

4. Савченко М. В. Творчество Л. С. Силантьевой - педагога, балетмейстера, руководителя народного театра балета «Вдохновение» // Ученые записки (Алтайская государственная академия культуры и искусств). Танцевальное искусство и образование. 2018. № 4 (18). C. $43-51$.

5. Бурцева Г. В. Воспоминания об организации балетной студии в Алтайском государственном театре музыкальной комедии // Ученые записки (Алтайская государственная академия культуры и искусств). Танцевальное искусство и образование. 2018. № 4 (18). С. 29-36.

6. Рылеева Н. Г. Педагогическая деятельность Н. Н. Кровяковой в народном ансамбле классического танца «Эос» // Ученые записки (Алтайская государственная академия культуры и искусств). Танцевальное искусство и образование. 2018. № 4 (18). С. 39-43.
Е. В. Ваганова, кандидат исторических наук, доцент Восточно-Сибирский государственный институт культуры (Улан-Удэ, Россия) ev_vaganova@mail.ru

С. Э. Эрдынеева Восточно-Сибирский государственный институт культуры (Улан-Удэ, Россия) sneg_idet97@bk.ru

\section{ЛИЧНЫЙ АРХИВНЫЙ ФОНД КСЕНИИ МАКСИМОВНЫ ГЕРАСИМОВОЙ КАК ИСТОРИЧЕСКИЙ ИСТОЧНИК}

Аннотация. Данная статья посвящена личному архивному фонду Ксении Максимовны Герасимовой, хранившемуся в Центре восточных рукописей и ксилографов Института монголоведения, буддологии и тибетологии Сибирского отделения Российской академии наук. Основное содержание исследования представляют документы личного характера и документы научной и общественной деятельности ученого. В работе более подробно описаны блокадные дневники К. М. Герасимовой, которые несут большую ценность и являются ценным историческим источником.

Ключевые слова: архив, личный архивный фонд, исторический источник, ученый, Герасимова Ксения Максимовна, буддология, музейное дело, Музей истории Бурятии им. М. Н. Хангалова, кониุепนฺия. 